\title{
THE INFLUENCE OF HAIL AND TREATMENTS WITH AMINO-ACIDS ON THE FERTILITY AND BIOLOGIC BALANCE OF GRAPEVINES
}

\author{
S. Banițăă1,2, A. Sestraș ${ }^{1}$, I. Olteanu ${ }^{3}$, A. Călugăr ${ }^{1}$ and C.I. Bunea ${ }^{*}$
}

1 Faculty of Horticulture, Advanced Horticultural Research Institute of Transylvania, Viticulture and Oenology Department, University of Agricultural Sciences and Veterinary Medicine Cluj-Napoca, 3-5 Mănăştur Street, Cluj-Napoca, Romania

2 Crama SERVE, Comuna Ceptura 125 C, Prahova County, ROMANIA

3 Faculty of Agriculture, University of Agricultural Sciences and Veterinary Medicine Cluj-Napoca, 3-5 Mănăştur Street, Cluj-Napoca Romania

* Corresponding author: claudiu.bunea@usamvcluj.ro

\begin{abstract}
Climatic accidents increase in frequency due to climatic changes. Hailstorms are typically localized events and are known few studies about their effect on grapevine. The objective of this study was to examine the vine vegetative balance responses to natural hail, registered when shoots were $10-15 \mathrm{~cm}$ height. Four grape cultivars (Vitis vinifera L.), two for red wine (Fetească Neagră, Pinot Noir) and two for white wine (Chardonnay, Tămâioasă românească) were studied in Dealu Mare, one of the most known vineyards in Romania. Visibly, the extent of the hailstorm damage was great, enough to injure or remove about $90 \%$ of shoots growth till hail fall. Three treatments with Delfan Plus (amino-acids complex) were applied on grapevine canopy. Number of shoots/vine and number of fertile shoots/vine were counted and biologic balance of grapevine indexes were calculated. Our results indicated that natural hail affect significantly the number of fertile shoots. Delfan Plus treatments positively influenced the number of shoots and fertile shoots. Delfan Plus treatments had little influence on Recovery index, vine Balance indexes and Ensurance Coefficient after one single year of study. The capacity of recovery after hail fall, in this case, is more influenced by the grape cultivar. The present work is the first attempt to enhance our understanding on the vegetative responses of grapevines to the use of biostimulants and to natural hail, which is an extreme and complex natural phenomenon.
\end{abstract}

Keywords: grapevine, Delfan Plus, fertile shoots, self-regeneration index, ensurance coefficient

\section{INTRODUCTION}

Hail represents an important climatic risk, although it occurs quite rarely. In a short time it can cause major material damage in the vineyards, having a direct impact on growth, 
harvest and last, but not the least, on the quality of grapes as raw material (Bora et al., 2014; Bora et al., 2016; Stafne and Carroll, 2019). Hail falls can have a destructive effect on vineyards, depending on the intensity, size and timing of the fall, causing significant damage, compromising grape production in that year, even influencing next year's production (Teodor, 2018). In Romania, the highest frequency of hail falls is found in the hills areas of the country, where the average number of hail days per year can reach up to 11.8 days/year (northwestern Romania). In the viticultural region of the hills of Muntenia and Oltenia, the average number of days with extreme phenomena represented by the hail fall is 0.3-0.8 days/year (Burcea and Cică, 2016). In wine regions, hail can occur throughout the year, but with a very low frequency in the cold season, while the period April-September representing $94 \%$ of the total average monthly hail days, reach its maximum in summer, more precisely in July (Istrate et al., 2015). The use of biostimulants could ensure food security with a limited increase in agricultural land, a sustainable strategy is to increase plant resistance and resilience to counteract climate change-induced stresses (Calvo et al., 2014). Biostimulants have a low toxicity for the long term, and are less prone to select resistans strains of pests and pathogens, and, therefore, can be considered environment and human friendly. The biostimulants market has increased in the last two decades, and will range around USD 1.5-2 billion in 2022 only in Europe (EBIC). These biostimulants, along with the improvement of plant growth and production, also are helpful to improve the yield and yield nutritional quality when applied exogenously through different modes (Ali et al., 2020). Petcu et al, 2007, certifies that the use of fertilizers containing amino-acids, ensures an easier transition to plant stressors, caused by extreme events such as: low temperatures, hail, water stress. Even though several studies have been conducted on the effect of extreme weather events on grapevine growth and physiology (Călugăr et al., 2009; Keller et al., 2016), as well as on grape and wine quality (Greer and Weedon, 2013; Bal et al., 2014), it is not clear yet what effects hailstorms have, directly or indirectly, on grapevine performance to recover its canopy. Due to this reason, we studied the effects of natural hail on some important cultivars in Romania (Tămâioasă românească, Fetească neagră, Pinot Noir, Chardonnay) establishing its impact on vegetative growth and vine balance.

\section{MATERIALS AND METHODS}

The research was carried out during 2019 and 2020, on four Vitis vinifera L. cultivars Tămâioasă românească, Fetească neagră, Pinot Noir and Chardonnay, at Serve winery, Ceptura wine growing center, Dealu Mare vineyard. The vines were plantated as follow: Pinot Noir in 2003, Fetească neagră and Chardonnay in 2006 and Tămâioasă românească in 2016. Planting distance was $2.2 \mathrm{~m}$ between rows and $0.9 \mathrm{~m}$ between vines/row, with a density of 5050 vines/ha. The vines were trained as simple Guyot ( 1 canes - $8-10$ buds and 1 spur/vine) or double Guyot ( 2 or 3 canes $-9-10$ buds and 2 spurs/vine) and pruned as follow:

Chardonnay - simple Guyot - 2019 - 12 buds/vine; 2020 - 13 buds/vine;

Tămâioasă românească - simple Guyot - 2019 - 11 buds/vine; 2020 - 13 buds/vine; Pinot Noir - simple Guyot - 2019 - 11 buds/vine; 2020 - 13 buds/vine.

Fetească Neagră - double Guyot - 2019 - 24 buds/vine; 2020 - 25 buds/vine.

On April 30th 2019, the hail that felt in Ceptura wine growing center, damaged $90 \%$ of shoots. The shoots were 10-15 cm height, uniformly growth and in good phitosanitary shape (Figure 1). In 30 minutes felt an amount of $25 \mathrm{~mm} / \mathrm{m}^{2}$ of rain. On May $2^{\text {nd }}$, at 2 days after the hail felt, a contact funcigide (Funguran $\mathrm{OH}, 2 \mathrm{l} / \mathrm{ha}$ ) was applied (Figure 2). The damaged shoots were cut down to stimulate the growth of dormant, secondary and coronary buds (Figure 3). Treatments with amino-acids (Delfan Plus) were applied at 20-25 cm shoots 
lenght, at 35-40 cm shoots lenght and at berries growth (treated variant) (Figure 4). Also, during vegetative period, nine phitosanitary treatments using contact and systemic pesticides were applied. After 4 weeks, the new shoots (from secondary and dormant buds) on 30 control vines and on 30 Deflan Plus treated vines were counted. During dormancy, the canes of vines were also counted and vegetative indexes were calculated as follow:

Recovery index $(\mathrm{RI})=$ no. of canes from multiannual wood $/$ no. of replaceble spurs at pruning ( $\mathrm{RI}=1$ - vine balance; $\mathrm{RI}<1$ - low vigor; $\mathrm{RI}>1$ - high vigor).

Balance index $=$ no. of fertil canes $/$ no. of two years canes $(\mathrm{BI}=1-$ vine balance; $\mathrm{BI}<1-$ low vigour; $\mathrm{BI}>1$ - high vigor)

Ensurance coefficient $=$ Recovery index + Balance index $(\mathrm{EC}=2-$ vine balance; $\mathrm{EC}<2-$ low vigour; EC > 2 - high vigor).

Statistical Analysis. Number of shoots and number of fertile shoots and the influence of treatment and year on those parameters was evaluated by statistical methods using the Duncan test ( $\mathrm{p} \leq$ 0.05), SPSS Version 24 (SPSS Inc., Chicago, IL., USA).

\section{RESULTS AND DISCUSSIONS}

According to Irimia et al. (2017), in the last three decades in the viticultural areas of Muntenia and Oltenia were recorded the following climatic conditions: the sum of active temperature $3192^{\circ} \mathrm{C}$, average temperature in the growing season $17.7^{\circ} \mathrm{C}$, precipitation level $392 \mathrm{~mm}$, sunshine duration 1509 hours and a mean oenoclimatic aptitude index of 4599 . This climatic data, reveals the suitability of this region for growing red and white wine cultivars.

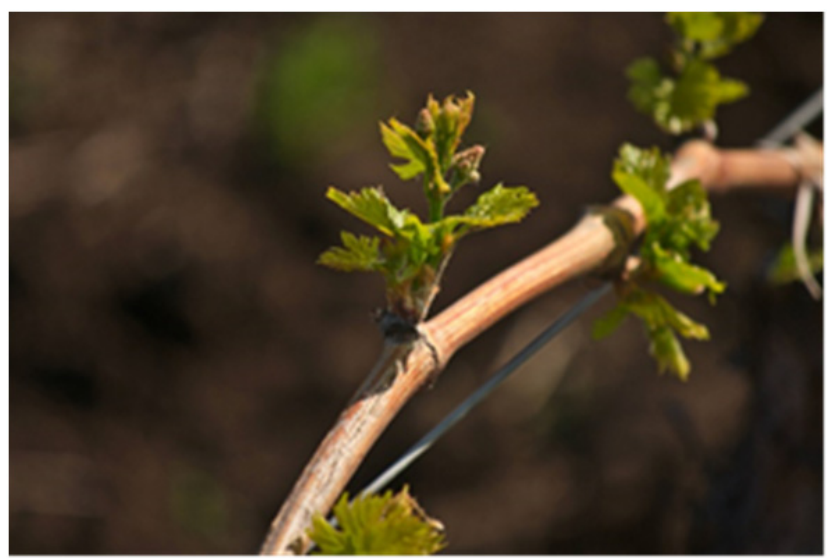

Figure 1. Shoots before hail fall

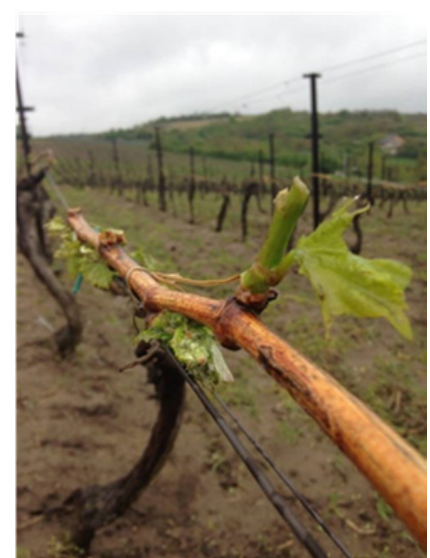

Figure 2. Shoots after hail fall, $90 \%$ damage

At 10-14 days after the hail fall, the growth of the shoots was achieved by dividing the cells and elongating the preformed internodes in the bud phase, by the energy stored at the cellular level. Subsequently, the development of the shoot intensified due to the entry into activity of the intercalary meristems, of the internodes and the formation of new vegetative growths that under the influence of photosynthesis, determined the formation of a rich foliar canopy (Poni et al., 2009).

Simultaneously with the growth of the shoots, there was also the growth of the afferent organs (leaves, lateral shoots, inflorescences, grapes) and the differentiation of the fruit elements for next year. 


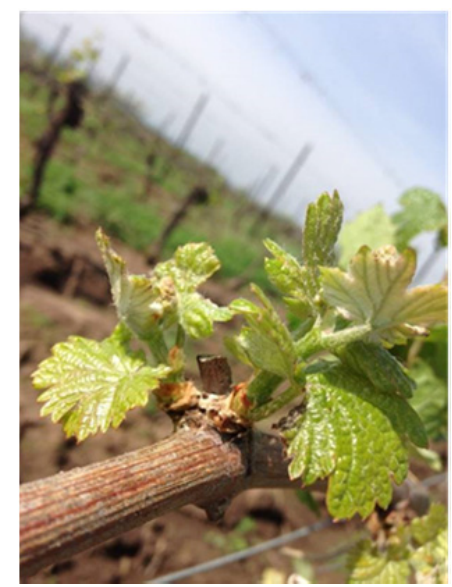

Figure 3. Vine recovery - shoots from secondary buds

Regarding the influence of hail on the vegetative organs, the lack of bud load stimulated significant increases of the foliar apparatus. The number of shoots/vine was slightly influenced, depending on the cultivar and the variant treated with amino-acids.
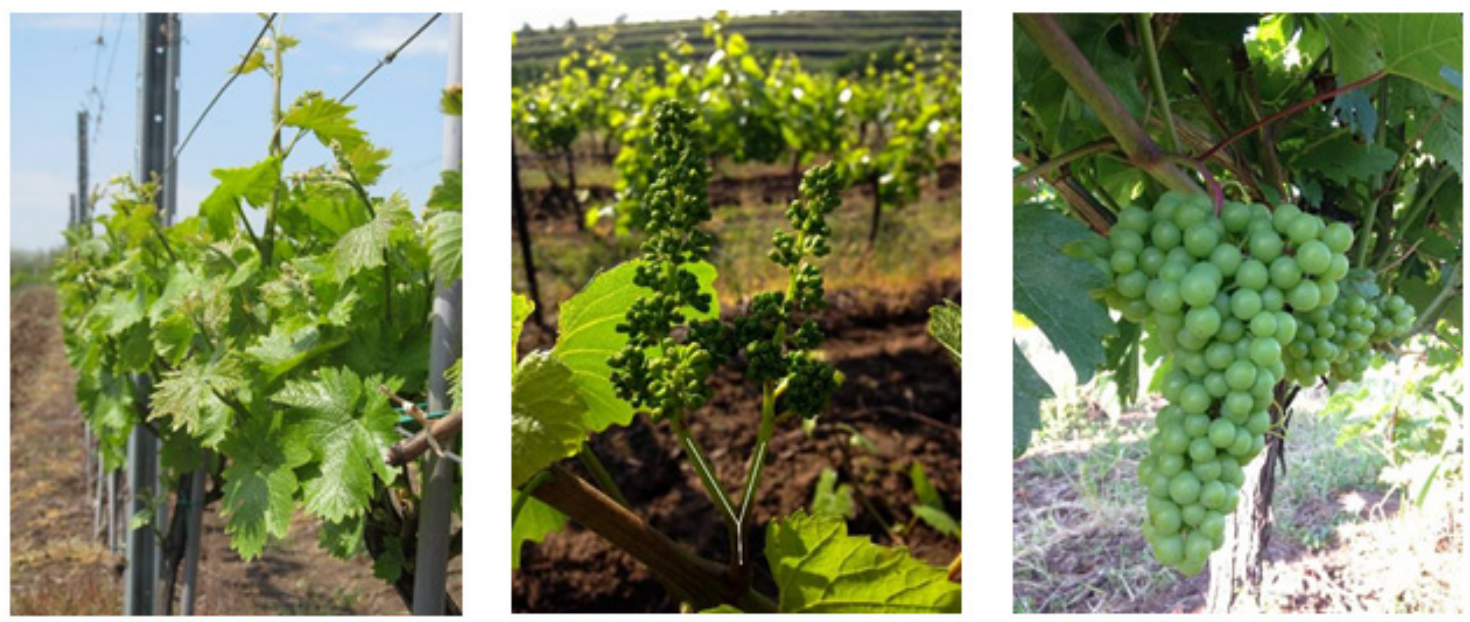

Figure 4. Moments of treatments with Delfan Plus, during 2019

(left - 2 weeks after hail, centered - 3 weeks after hail, right - 12 weeks after hail)

As it may be seen in Figure 5, the number of shoots on vines were close for Chardonnay, Pinot Noir and Tămâioasă românească cultivars in both variants and both years. Although, there are some significant difference between the variants at Tămâioasă românească, with 13.97 shoots/vine on Delfan Plus treatement and 12.50 shoots/vine for Control, in 2019. An interesting situation for this cultivar is that, the following year, the Control recorded higher number of shoots (13.88 shoots/vine) compared with treated variant (11.47 shoots/vine). Fetească Neagră registered the most significant difference between the studied year regarding the number of shoots per vines, but no influence between variants (treated and control) (Figure 5). 


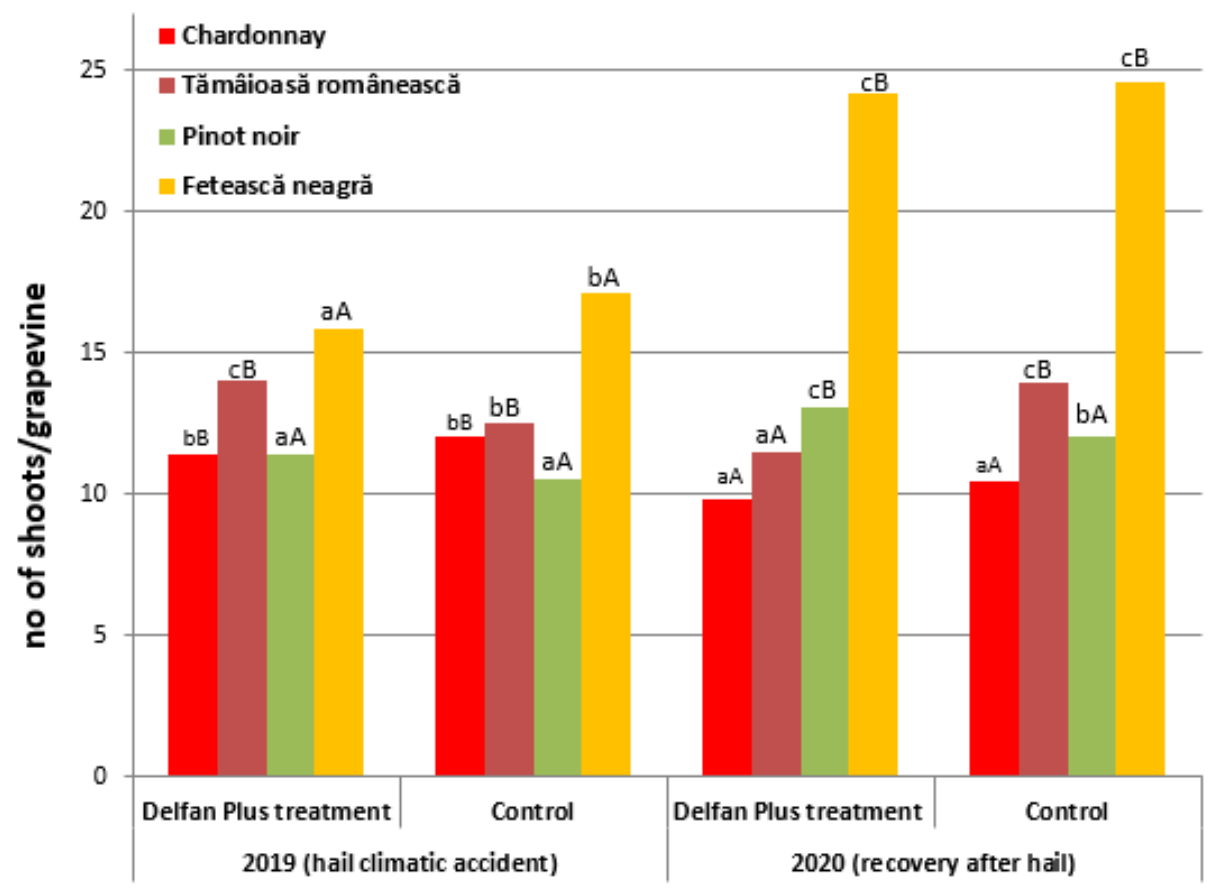

Figure 5. The number of shoots on grapevine for the two variants (Control and Delfan Plus treatment)

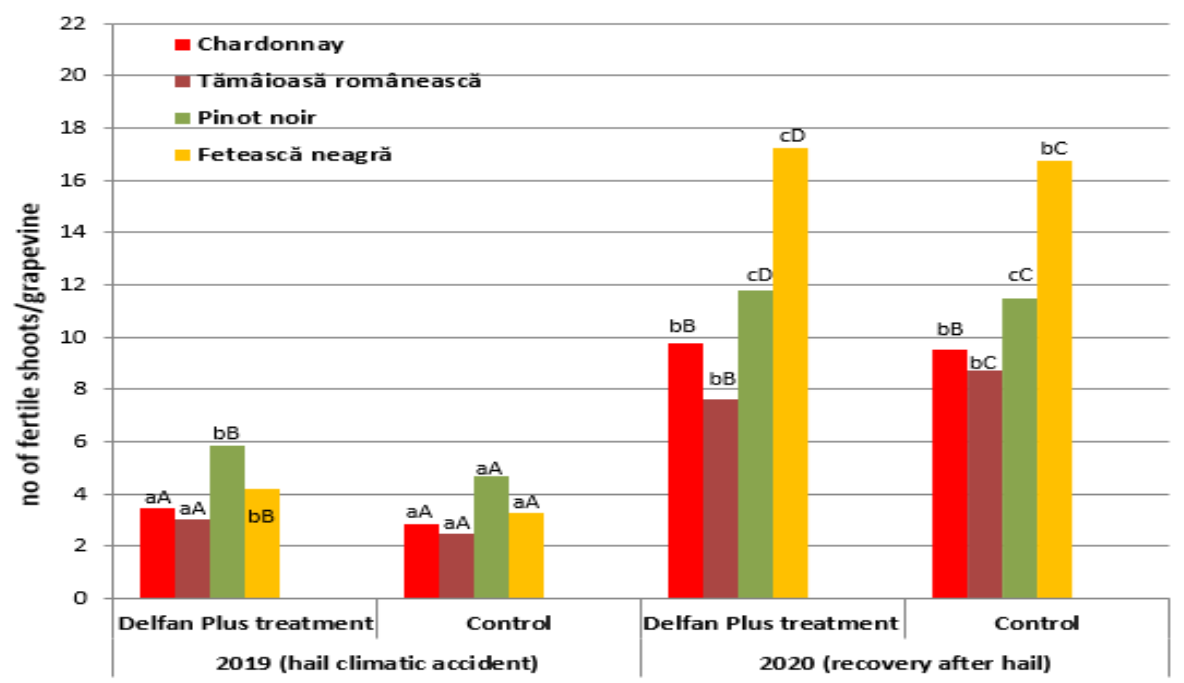

Figure 6. The number of fertile shoots on grapevine, on Delfan Plus treated variant and Control, during 2019 and 2020

Lowercase letters represent the significance of the cultivar difference between traeted and control varints $(\mathrm{p} \leq 0.05)$. Uppercase letters represent the significance of the same cultivar in the two years $(p \leq 0.05)$. The difference between any two values, followed by at least one common letter, is insignificant.

The fertility of the cultivar represents its property to generate and form fruitage organs, the level of fruitage being different from one cultivar to another, to the same cultivar from one vine to another, from one year to another (Candolfi-Vasconcelos and Koblet, 1990). 
The low percentage of fertile shoots on the stem and a small number of inflorescences on the stem is directly influenced by the damage caused by hail. The average number of fertile shoots differs significantly for all cultivars observed in the two years of research (2019 and 2020), but also between Treated and Control variants.

It is very clearly from Figure 6., that hail have an important influence on the number of fertile shoots, with the lower values for both variants (Treated and Control) for all the studied cultivars.

Chardonnay and Tămâioasă românească cultivars, recorded similiar fertile shoots number for variant treated with Delfan Plus and Control in the year 2019, after hail fall. In 2020, significant differences between variants (treated and control) were recorded for Tămâioasă românească, Pinot Noir and Fetească Neagră, with higher number of fertile shoots for Delfan Plus treated variant.

The share of fertile shoots or unfertile shoots (suckers) on vine depending on the cultivar is represented in the Figure 7. The values were divided and compared according to the Treatments performed with amino-acids and Control.

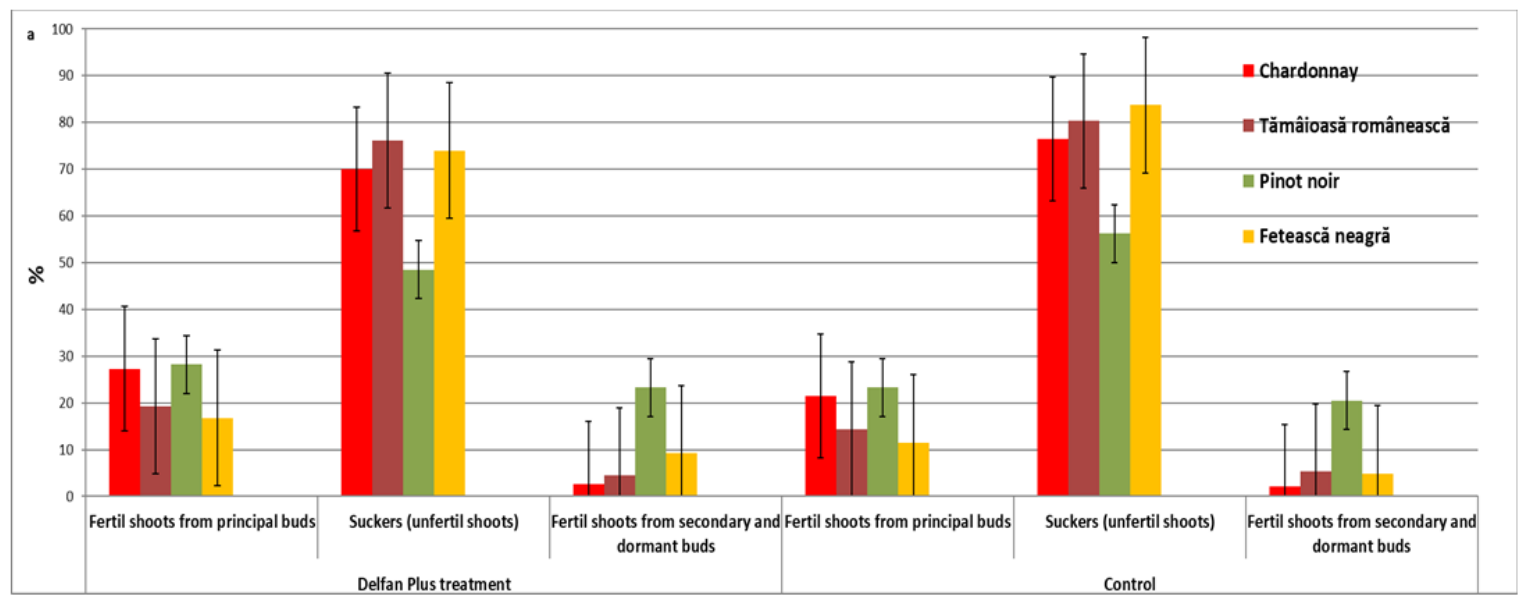

Figure 7. The percentage of fertile shoots, unfertile shoots (suckers) and fertile shoots from secondary and dormant buds, on grapevines, in 2019 period of vegetation

For all the studied cultivars, the percentage of fertile shoots from principal buds and fertile shoots from secondary and dormant buds were higher for Treated variants compared to Control. After treatment with Delfan Plus, Chardonnay recorded $27 \%$ fertile shoots from principal buds and $21 \%$ shoots from secondary and dormant buds, values higher compared to Control, $21 \%$ and 2,1 \%, respectively. Similar results were observed for Pinot Noir (Figure 7). The percentage of fertile shoots, as an index of fertility and production, is of great interest in the choice of vine cultivars and in the profitability of plantations (CandolfiVasconcelos and Koblet, 1990). It varies depending on the fertility of the cultivar but also on other factors.As previously observed by Petoumenou et al., 2019, lateral shoots could provide assimilates to support their own growth and sending the surplus to the main shoot, which contributed to harvest rippening.

The evaluation of the vegetative biological balance of the vines is performed based on the Recovery Index (RI), Balance Index (BI) and Ensurance Coefficient (EC). With the help of these indices, one can appreciate the accuracy of the initial bud load established last year and the pruning correction of the current year. The vegetative biological balance exists when the aerial part and the root system satisfy each other and fully meet the need for 
metabolic substances, and the biomass production of the trunk is maintained in balance year after year (Irimia, 2006).

Among grapevine cultivars, the highest values of Self-regeneration index were obtained for Tămâioasă Românească (10.6 - Delfan Plus treatment and 10.0 - Control), followed by Fetească Neagră cultivar (9.7 - Delfan Plus treatment and 11.4 - Control). The lowest results were obtained for the Pinot Noir cultivar (5.5.- Delfan Plus treatment and 5.9 - Control). As it may seen from Table 3, the values of vegetative balance index of grapevine have close values between treated and control variant. This fact could indicate that Delfan Plus treatments had no significant influence on those indexes, after one single year of study. The capacity of recovery after hail fall, in this case, is more influenced by the grape cultivar (Poni et al., 2006). Also, as it was showed in previous results, that Delfan Plus treatment, have influnced the fertility of shoots for the following vintage year.

The high values, both of the Balance Index (BI) and of the Recovery Index (RI) in 2019 for all the cultivars, reflect the tendency of the vines to recover their aerial part (shoots started in vegetation) lost due to hail fall, based on dormant and secondary buds. From those buds, arise unfertile and fertile shoots, which generate the accumulation of substances necessary for the development of the root system, then sustaining in the following year (2020) a much higher bud load.

Table 1. The indexes of vegetative balance of grapevine, after hail fall and treatments with Delfan Plus

\begin{tabular}{|c|c|c|c|c|c|c|}
\hline & \multicolumn{2}{|c|}{ Recovery Index } & \multicolumn{2}{c|}{ Balance Index } & \multicolumn{2}{c|}{ Ensurance Coefficient } \\
\cline { 2 - 7 } & Control & $\begin{array}{c}\text { Delfan Plus } \\
\text { treatment }\end{array}$ & Control & $\begin{array}{c}\text { Delfan Plus } \\
\text { treatment }\end{array}$ & Control & $\begin{array}{c}\text { Delfan Plus } \\
\text { treatment }\end{array}$ \\
\hline Chardonnay & 9,2 & 8,0 & 2,0 & 2,0 & 11,2 & 10,0 \\
\hline $\begin{array}{c}\text { Tămâioasă } \\
\text { românească }\end{array}$ & 10,0 & 10,6 & 2,0 & 2,0 & 12,0 & 12,6 \\
\hline Pinot Noir & 5,9 & 5,5 & 2,0 & 2,0 & 7,9 & 7,5 \\
\hline $\begin{array}{c}\text { Fetească } \\
\text { Neagră }\end{array}$ & 11,4 & 9,7 & 2,0 & 2,0 & 13,4 & 11,7 \\
\hline
\end{tabular}

Although large work has been done to study the role of biostimulants in improving plant growth and production, still more is required for final recommendations. More attention is required in this regard for the future, due to their non-toxic and environmentalfriendly nature.

\section{CONCLUSIONS}

The present study is the first attempt in quantifying natural hail effects on vegetative balance on some wine grapes cultivars. Based on the results, the natural hailstorm caused an alteration in vegetative growth on Chardonnay, Pinot Noir, Tămâioasa românească and Fetească Neagră (V. vinifera L.) grapevines due to shoots damage induced by the hailstorm. The treatments with biostimulators such as Delfan Plus after hail and the following year, help grapevine to recover vegetative canopy with significant increases compared with control variant (wihtout treatment). Moreover, this phenomenon implicates physiological and vegetative responses that can bring the vines to an acceptable vine balance index and bud fertility in the following season. Further investigation of these effects (maybe in the presence of greater hail-damage impacts) could be useful for better understanding the responses of grapevines under extreme abiotic conditions. 


\section{REFERENCES}

1. Ali Q., Shehzad F., Waseem M., Shahid S., Hussain A.I., Haider M.Z., Habib N., Hussain S.M., Javed M.T. \& Perveen R. (2020) Plant-Based Biostimulants and Plant Stress Responses. In: Hasanuzzaman M. (eds) Plant Ecophysiology and Adaptation under Climate Change: Mechanisms and Perspectives I. Springer, Singapore.

2. Bal S. K., Saha S., Fand B. B., Singh N. P., Rane J. \& Minhas P. S. (2014). Hailstorms: Causes, Damage and Post-hail Management in Agriculture. Technical Bulletin No. 5, National Institute of Abiotic Stress Management, Malegaon, Baramati.413 115.Pune, Maharashtra (India).p. 44.

3. Bora F.D., Pop T.I., Bunea C.I., Urcan D.E., Babeș A., Mihaly-Cozmuta L., Mihaly-Cozmuta A. \& Pop N. (2014). Influence of Ecoclimatic and Ecopedological Conditions on Quality of White Wine Grape Cultivars from North-West of Romania, Bulletin UASVM Horticulture 71(2): 218-225. DOI:10.15835/buasvmcnhort:10545.

4. Bora F.D., Dina I., Iliescu M., Zaldea G. \& Guță I.C. (2016). Analysis and Evaluation of the Main Ecoclimatic Conditions from Romanian Vineyards.Bulletin UASVM Horticulture. 73(2):221-223.

5. Burcea S., Cică R. \& Bojariu R. (2016). Hail Climatology and Trends in Romania in 1961-2014. American Meteorological Society. 144:4289-4299.

6. Calvo P., Nelson L. \& Kloepper J.W. (2014). Agricultural uses of plant biostimulants.Plant Soil. 383:3-41.

7. Candolfi-Vasconcelos, M.C. \& Koblet, W. (1990). Yield, fruit-quality, bud fertility and starch reserves of the wood as a function of leaf removal in Vitis vinifera-Evidence of compensation and stress recovering. Vitis. 29:199-221.

8. Călugăr A., Pop N., Farago M., Babeș A., Hodor D. \& Bunea C.I. (2009). Influence of Critical Environmental Factors on Elements of Fertility at Grape Cultivars Created at S.C.D.V.V. Blaj. Bulletin UASVM Horticulture 66(1):255-259.

9. EBIC - European Biostimulants Industry Council. Available online: http://www.biostimulants.eu/ (accessed on 30 october 2020)

10. Greer D.H. \& Weedon M.M. (2013). The impact of high temperatures on Vitis vinifera cv. Semillon grapevine performance and berry ripening.Frontiers in Plant Science. 4:1-9.

11. Irimia L. (2006) Influența tăierilor scurte de rod asupra potențialului vegetative și de producție la soiurile de viță de vie pentru struguri de vin, din centrul viticol Averești - Podgoria Huși, Teză de doctorat, USAMV Ion Ionescu de la Brad, Iași, p:282.

12. Istrate V., Axinte A-D., Apostol L., Florea D. \& Machidon O.-M. (2015). The efficacity of hail supression in Iași county (Romania) case study 09 July 2015, Conference:16 th International Multidisciplinary Scientific GeoConference SGEM, Albena, Bulgaria, Volume 2: Air Pollution and Climate Change. DOI: 10.5593/SGEM2016/B42/S19.081

13. Keller M., Romero P., Gohil H., Smithyman R.P., Riley W.R., Casassa L.F. \& Harbertson J.F. (2016). Deficit irrigation alters grapevine growth, physiology, and fruit microclimate. American Journal of Enology and Viticulture. 67:426-435.

14. Petcu E., Ţerbea M. \& Lazăr C. (2007). Cercetări în domeniul fiziologiei plantelor de câmp la Fundulea, Volum omagial fiziologia plantelor. AN. I.N.C.D.A. Fundulea, vol. LXXV.

15. Petoumenou D., Biniari K., Xyrafis E., Mavronasios D., Daskalakis I. \& Palliotti A. (2019). Effects of Natural Hail on the Growth, Physiological Characteristics, Yield, and Quality of Vitis vinifera L. cv. Thompson Seedless under Mediterranean Growing Conditions, Agronomy. 9:197; doi:10.3390/agronomy9040197

16. Poni S., Bernizzoni F., Civardi S. \& Libelli N. (2009). Effects of pre-bloom leaf removal on growth of berry tissues and must composition in two red Vitis vinifera L. cultivars. Australian Journal of Grape Wine Research. 15:185-193.

17. Stafne E.T. \& Carroll B.L. (2019). Simulated Abiotic Injury Alters Yields of Southern Interspecific Hybrid Grape Cultivars.Horticulturae. 5: 44; doi:10.3390/horticulturae5020044

18. Teodor L. (2018). Muntean considerations regarding the use of anti-hail nets for the protection of table grape plantations in Hinova viticultural area, Mehedinti County. Scientific Papers.Series B, Horticulture. LXII:227-330. 